\section{PARAGUAY República del Paraguay}

\author{
Area: 406,752 sq. $\mathrm{km}$ \\ Population: 3,250,000 \\ Capital: Asunción \\ Head of State: Gen. Alfredo Stroessner (President) \\ Minister of the Interior: Dr Sabino A. Montanaro
}

Paraguay comprises 19 departments (Departamentos); capitals are in brackets):

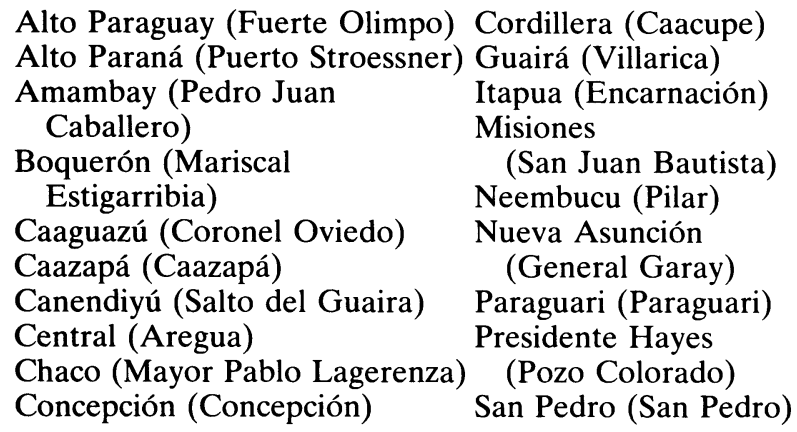

\section{ORGANIZATION}

The Paraguayan Police, which operates under the provisions of the August 1951 Police Law, is a centralized force comprising two main sections-one for the capital and another for the rest of the country.

Asunción has its own police force, the Policía de la Capital, divided into 23 borough precincts (Comisarias Seccionales). There are three departments: Public Order (Orden Público), Investigations (Investigaciones) and Training and Operations (Instrucción y Operaciones). The four main Directorates (Direcciones) are: Surveillance and Offences (Vigilancia y Delictos); Identification (Identificaciones); Alien Registration (Registos Extranjeros); and Politics (Política). Other police units include the Motorized Police (Policía Motorizada) and the Security Guard (Guardia de Seguridad). The Fire Department (Cuerpo de Bomberos) is also manned by police personnel, who are responsible for fire training and the maintenance of firefighting vehicles.
There are four training establishments, all at Asunción: the Police College (Colegio de Policía) for basic training; the Higher Police College (Colegio Superior de Policía) for specialist training, the NCO School (Escuela de SubOficiales); and the Police Training Battalion (Batallon de Instrucción Policial) for in-service training.

The Highway Police (Policía Caminera) operates under the authority of the Ministry of Public Works and Communications.

The internal security organ is the Directorate General of Investigations (Dirección General de Investigaciones, DGI), usually referred to as Investigaciones.

Policía de la Capital, El Paraguayo Independiente y Chile, Asunción (43 125)

Colegio de Policía, Villa Policía, Nu Guazu (66 008)

Colegio Superior de Policía, 14 de Julio y Chile, Asunción (49 344)

Escuela de Sub-Oficiales de Policía, El Paraguayo Independiente y Chile, Asunción (49 008)

Batallon de Instruccion Policial, Yegros y 24 Portada, Asunción (72 956)

Jefatura de Policía Caminera, Oliva y Alberdi, Asunción (45 204)

\section{OPERATIONS}

Most Paraguayans have a large proportion of Indian blood, and Guarani is commonly spoken, although Spanish is the official language. This homogeneity, and the government's strength, give Paraguay a lower crime rate than elsewhere in South America.

Even so, crime figures are slowly rising. There are less murders, but drug offences are more common than they were in the early 1970s. Crimes against the security of the state (contra la seguridad interna del Estado, as defined by Law 209) were relatively few, but rose alarmingly during 1982 . The following statistics were released in 1983:

$\begin{array}{ccccc}\text { total } & & & \\ \text { committed } & & \text { drug } & \text { state } \\ \text { year } & \text { to prison } & \text { murder } & \text { offences } & \text { security } \\ 1978 & 1527 & 251 & 84 & 1 \\ 1979 & 1695 & 216 & 159 & 3 \\ 1980 & 1772 & 257 & 100 & 3 \\ 1981 & 1851 & 209 & 116 & - \\ 1982 & 1839 & 188 & 159 & 34\end{array}$

